УДК 633.11.811.98

\title{
ОСОБЕННОСТИ ПРИМЕНЕНИЯ ПОЛИМЕРОВ НА ПОСЕВАХ ОЗИМОЙ ПШЕНИЦЫ
}

Бекалдиева Н.М. магистрант Альмов А.K. магистрант Хежева А.А. магистрант Тутов A.A. магистрант

Забаков А.Б. студент

Научный руководитель: Ханиева И.М. профессор ФГБОУ ВО Кабардино-Балкарский ГАУ

Аннотация: в статье приводятся данные результатов исследований по влиянию предпосевной обработки семян озимой пшеницы водным раствором

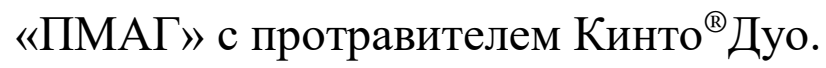

Ключевые слова: озимая пшеница, полимерный регулятор роста, протравитель, Кинто-Дуо, качество зерна.

Проблема продовольствия и обеспечения растущего населения планеты полноценным питанием сейчас стоит достаточно остро, она стала важным социальным, экономическим и политическим фактором в современном мире. В настоящее время большое значение придается получению экологически чистых видов продукции сельского хозяйства. Как следствие прогресса, помимо применения пестицидов, для поддержания оптимальной фитосанитарной обстановки посевов пшеницы и повышения иммунитета, появился ряд новых биологически активных веществ и смесей, влияющих на продуктивность и качество зерновых культур.

Одним из резервов повышения урожайности пшеницы, увеличения валовых сборов и улучшения качества зерна, является повсеместное 
применение прогрессивных технологий ее возделывания, разработанных с учетом почвенно-климатических условий. Эти препараты - полимерные стимуляторы роста растений. Их применение в сельском хозяйстве в последнее время многократно возросло. В связи с этим был заложен полевой опыт, экспериментальная часть которого проводилась в 2018-2020 гг., в условиях предгорной зоны Кабардино-Балкарии на территории УПК Кабардино-Балкарского ГАУ.

Опытный участок характеризовался следующими агрохимическими показателями: почва опытного участка чернозем выщелоченный, содержание гумуса в пахотном горизонте 3,8\%, щелочногидролизуемый азот - 148 мг/кг, реакция почвенного раствора нейтральная (рН-6,5). Содержание подвижного фосфора составляет 30 мг на 100 г почвы, то есть обеспеченность средняя (по Чирикову), обеспеченность обменным калием повышенная - 82 мг на 100 г почвы (по Чирикову). По механическому составу данная почва тяжелосуглинистая. Содержание в ней физической глины составляет 57,2\%.

В задачи наших исследований входило: установить влияние предпосевной обработки семян озимой пшеницы путем протравливания их водным раствором «ПМАГ» полиметакрилатгуанидина с молекулярной массой 500 тыс. усл. ед., с концентрацией 0,02-0,2\% и протравителем Кинто $^{\circledR}$ Дуо (BASF) с дозой 2,5 л/т при рабочем расходе 15 л на 1 т семян на энергию прорастания, всхожесть, паражаемость вредителями, урожайность и качество зерна озимой пшеницы.

В качестве объекта использовали сорт озимой пшеницы «Лауреат».

\section{Влияние предпосевной обработки семян озимой пшеницы} сорта Лауреат на энергию прорастания, всхожесть, поражаемость семян

Таблица 1

\begin{tabular}{|c|c|c|c|}
\hline Вид обработки & $\begin{array}{c}\text { Энергия } \\
\text { прорастания, \% }\end{array}$ & $\begin{array}{c}\text { Всхожесть } \\
\%\end{array}$ & $\begin{array}{c}\text { Поражаемость, } \\
\%\end{array}$ \\
\hline Вода (контроль) & 75 & 69 & 7 \\
\hline 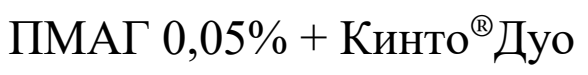 & 77 & 70 & 5 \\
\hline 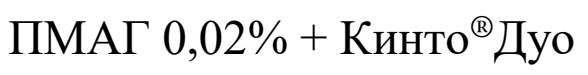 & 78 & 71 & 4 \\
\hline ПМАГ 0,01\% + Кинто Дуо & 87 & 72 & 2 \\
\hline 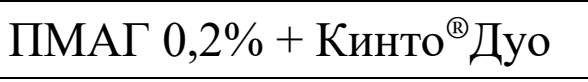 & 89 & 74 & 1 \\
\hline 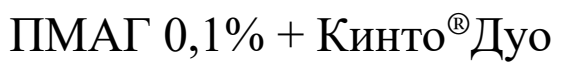 & 77 & 70 & 5 \\
\hline
\end{tabular}


Проведенные исследования показали, что увеличивается энергия прорастания и всхожесть озимой пшеницы при концентрации $0,2 \%$.

\section{Влияние предпосевной обработки семян озимой пшеницы} сорта Лауреат на урожайность

Таблица 2

\begin{tabular}{|c|c|c|}
\hline Варианты & Урожайность, ц/га & Прибавка, ц/га \\
\hline Вода & 32,7 & 0,0 \\
\hline 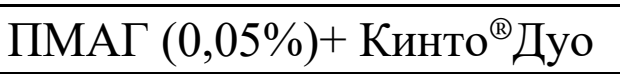 & 36,4 & 3,7 \\
\hline 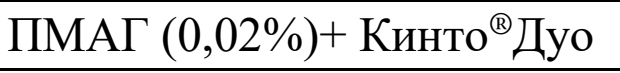 & 43,6 & 10,9 \\
\hline 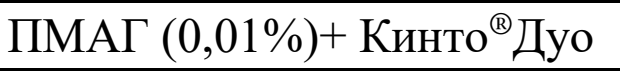 & 45,2 & 12,5 \\
\hline 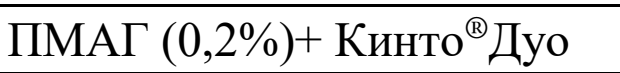 & 47,3 & 14,6 \\
\hline 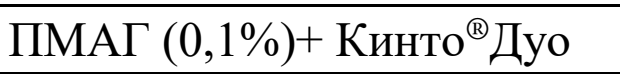 & 37,5 & 4,8 \\
\hline
\end{tabular}

$\mathrm{HCP}_{0,95}=1,3$

Ошибка опыта $(\%)=2,0$

Наибольшая прибавка также получена на варианте с концентрацией $0,2 \%$ и составила 14,6 ц/га.

Изучено влияние предпосевной обработки семян озимой пшеницы сорта Лауреат водным раствором «ПМАГ» полиметакрилатгуанидина с молекулярной массой 500 тыс. усл. ед., с концентрацией 0,02-0,2\% и протравителем Кинто ${ }^{\circledR}$ Дуо (BASF) с дозой 2,5 л/т при рабочем расходе 15 л на 1 т семян на показатели качества зерна озимой пшеницы.

\section{Влияние предпосевной обработки семян озимой пшеницы} на показатели качества зерна

Таблица 3

\begin{tabular}{|c|c|c|}
\hline \multirow[b]{2}{*}{ Варианты } & \multicolumn{2}{|c|}{ Зерно } \\
\hline & $\begin{array}{c}\text { Стекловидность } \\
\text { (в \%) }\end{array}$ & $\begin{array}{c}\text { Протеин } \\
\text { (в \%) }\end{array}$ \\
\hline Вода & 71,3 & 14,2 \\
\hline ПМАГ $(0,05 \%)+$ Кинто $^{\circledR}$ Дуо & 73,1 & 14,5 \\
\hline 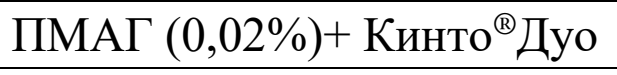 & 82,9 & 15,5 \\
\hline 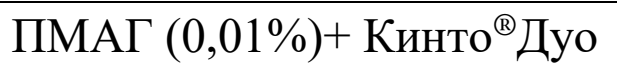 & 84,0 & 16,4 \\
\hline 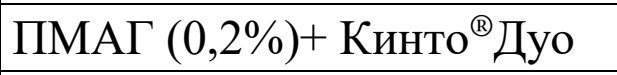 & 87,1 & 17,5 \\
\hline ПМАГ $(0,1 \%)+$ Кинто $^{\circledR}$ Дуо & 72,9 & 14,4 \\
\hline
\end{tabular}


Показатели стекловидности и содержание сырого протеина были максимальными на варианте с концентрацией $0,2 \%$ и составили 87,1 и $17,5 \%$ соответственно. Повышение продуктивности и качества зерна озимой пшеницы происходит за счет увеличения энергии прорастания, силы роста, лабораторной и полевой всхожести, снижения поражаемости растений болезнями и вредителями.

Следовательно, применение предпосевной обработки семян озимой пшеницы сорта Лауреат водным раствором «ПМАГ» полиметакрилатгуанидина с молекулярной массой 500 тыс. усл. ед., с концентрацией $0,02-0,2 \%$ и протравителем Кинто ${ }^{\circledR}$ Дуо (BASF) с дозой 2,5 л/т при рабочем расходе 15 л на 1 т семян позволяет упростить процесс предпосевной обработки семян, снизить трудоемкость этого процесса, а также стимулировать рост, развитие растений озимой пшеницы, повысить ее урожайность и качество.

\section{Список литературы}

1. Ханиева И.М. Продуктивность озимой пшеницы при применении подкормок и препарата «Байкал-ЭМ-1» в условиях КабардиноБалкарской республики [Текст] / К.Г. Магомедов, Ханиев М.Х., Бозиев А.Л., Кишев А.Ю. // Фундаментальные исследования. - 2008. - №55. - С. 33-34.

2. Злотников, А.К. Альбит на озимой пшенице / А.К. Злотников, А.И. Деров, И.И. Бегунов, К.М. Злотников// Земледелие, 2005. - №3. C. 31-32.

3. Магомедов К.Г. Продуктивность озимой пшеницы при применении подкормок и препарата "Байкал-ЭМ-1" в условиях КабардиноБалкарской Республики/Магомедов К.Г., Ханиев М.Х., Ханиева И.М., Бозиев А.Л., Кишев А.Ю.//Фундаментальные исследования. 2008. № S5. C. 33-34.

4. Мамсиров, Н.И. Влияние минеральных удобрений и регуляторов роста на продуктивность озимой пшеницы в Адыгее / Н.И. Мамсиров, 3.Ш. Дагужиева //Новые технологии. - 2016. - № 2. - С. 117-123.

5. Кишев А.Ю. Агробиологические условия продуктивности фотосинтетической деятельности посевов озимой пшеницы в условиях процесса биологизации сельского хозяйства [Текст] / Т.Б. Жеруков, Кишев А.Ю. // Международные научные исследования. - 2016. - №4. С. 8-10. 
6. Кишев А.Ю. Регуляторы роста растений и технологические показатели качества зерна озимой пшеницы при возделывании в условиях степной зоны КБР [Текст] / Т.Б. Жеруков, Кишев А.Ю. // Международные научные исследования. - 2016. - №4. - С. 21-24.

7. Кишев А.Ю. Приемы повышения продуктивности озимой пшеницы в условиях предгорной зоны Кабардино-Балкарской республики [Текст] / Шибзухов 3.С. // Устойчивое развитие: проблемы, концепции, модели. Материалы Всероссийской конференции с международным участием, посвященной 75-летию председателя ФГБНУ «Федеральный научный центр «Кабардино-Балкарский научный центр Российской академии наук», доктора технических наук, профессора П.М. Иванова. 2017. С. 291-293. 